\title{
EXPERIMENTAL DETERMINATION OF CONTINUOUS COOLING TRANSFORMATION DIAGRAM FOR HIGH STRENGTH STEEL X155CrMoV12
}

\author{
Received - Primljeno: 2021-05-06 \\ Accepted - Prihvaćeno: 2021-08-25 \\ Original Scientific Paper - Izvorni znanstveni rad
}

The article is a result of investigations which deals with the phase transformations of tool steel X155CrMoV12. The experimental data obtained was used to evaluate the resulting Continuous Cooling Transform (CCT) diagram, which consists of seven dilation curves. All experimental samples from dilatometric analyzes were then subjected to microstructural analyzes and hardness measurements to characterize the microstructure and hardness for each heat treatment mode tested. Atomic Force Microscopy (AFM) microscopy was also used to study the carbides present in steels and their size and shape for all selected cooling modes.

Keywords: dilatometry, X155CrMoV12, cooling rate, microstructure, CCT diagram

\section{INTRODUCTION}

In practical situations, CCT diagram play an important role in the development of high-strength advanced steels. The CCT diagrams allow accurate predictions of the microstructures compositions that may arise in the real processing of these steels. They are generally used to design and optimize special heat treatments and predict the resulting microstructures and mechanical properties [1]. These phase transformation curves provide precise information about microstructure resulting from non-isothermal austenite decomposition. The resulting diagrams serve the needs of the metallurgical industry for further heat treatment of steel.

Unfortunately, the availability of CCT diagrams created for transformation of intercritical austenite practically does not exist in open literature and therefore the mechanisms of transformation are not fully understood. Respectively, diagrams can be obtained using various software, but their use is more informative than scientific, since all of these software have to limit their field of activity many times by the percentage limitation of the composition of steels.

\section{MATERIALS AND METHODS}

The base material used in the performed experiments is high alloyed tool steel X155CrMoV12 (Table 1) used

\footnotetext{
M. Krbat’a, michal.krbata@tnuni.sk, J. Majerík, jozef.majerík@tnuni. sk, I. Barényi, igor.barenyi@tnuni.sk, M. Eckert, maros.eckert@tnuni. sk, Faculty of Special Technology TnUAD Trenčín, Slovak Republic. R. Čep, robert.cep@vsb.cz, Faculty of Mechanical Engineering VSBTU Ostrava, Czech Republic.

J. Sedlák, sedlak@fme.vutbr.cz, Faculty of Mechanical Engineering FSI VUT Brno, Czech Republic.

I. Samardžić, isamardzic@unisb.hr, Mechanical Engineering Faculty, University of Slavonski Brod, Croatia.
}

Table 1 Chemical composition of the X155CrMoV12 examined steel / wt. \%

\begin{tabular}{|c|c|c|c|}
\hline ISO 4967 & Min & Max & Spectral analysis \\
\hline $\mathrm{C}$ & 1,45 & 1,60 & 1,53 \\
\hline $\mathrm{Mn}$ & 0,20 & 0,60 & 0,40 \\
\hline $\mathrm{Si}$ & 0,10 & 0,40 & 0,35 \\
\hline $\mathrm{Cr}$ & 11,00 & 13,00 & 12,00 \\
\hline $\mathrm{Mo}$ & 0,70 & 1,00 & 1,00 \\
\hline $\mathrm{V}$ & 0,70 & 1,00 & 1,00 \\
\hline
\end{tabular}

Table 2 Basic mechanical properties of the X155CrMoV12 steel

\begin{tabular}{|c|c|c|c|}
\hline $\begin{array}{c}\text { Mechanical } \\
\text { and physical } \\
\text { properties }\end{array}$ & $\begin{array}{c}\text { Tensile strength } \\
R_{m} / \mathrm{MPa}\end{array}$ & $\begin{array}{c}\text { Young's } \\
\text { modulus } E / \mathrm{GPa}\end{array}$ & $\begin{array}{c}\text { Hardness* } \\
\mathrm{HV} 5\end{array}$ \\
\cline { 2 - 4 } & 2180 & 210 & 790 \\
\hline
\end{tabular}

*quenched to oil

in engineering industry. It is chromium vanadium steel with high hardenability suitable for quenching in oil and air [2]. The steel is characterized by high wear resistance and very high tensile strength (up to $2180 \mathrm{MPa}$ ) and is mostly used for cutting tools, such as stretching and extruding mandrels, profile blades and complex shaped milling cutters. Its basic mechanical properties can be seen in Table 2.

\section{Atomic force microscopy}

Images were directly obtained using the MFP-3D Infinity AFM microscope (Oxford Instruments). Surface scanning was realized using the AC Air Topography mode, where the cantilever tip is not in constant contact with the tested surface, but is vibrates near its resonance frequency and tapes the surface to obtain information of the topography of the tested sample surface. Since this is a relatively high-strength sample, the AC 160TS-R3 can- 
tilever with the spring constant $26 \mathrm{~N} / \mathrm{m}$, resonance frequency $300 \mathrm{~Hz}$ and the tip radius in range $5-10 \mathrm{~nm}$ was used for the all performed measurements [3, 4].

\section{RESULTS AND DISCUSSION}

\section{Microstructure}

As is already known, the austenite decomposition and finally formed phases depend on cooling rate. This course of austenite decomposition during continuous cooling corresponds to the discontinuity of the slope detected in the dilatometric curves and is related to the temperature range of specific microstructure type formation. Although the temperature ranges, in which the various phase transformations in the steel can occur, are relatively wide and may even overlap, every phase transformation occurred during the overall continuous cooling process could be detected.
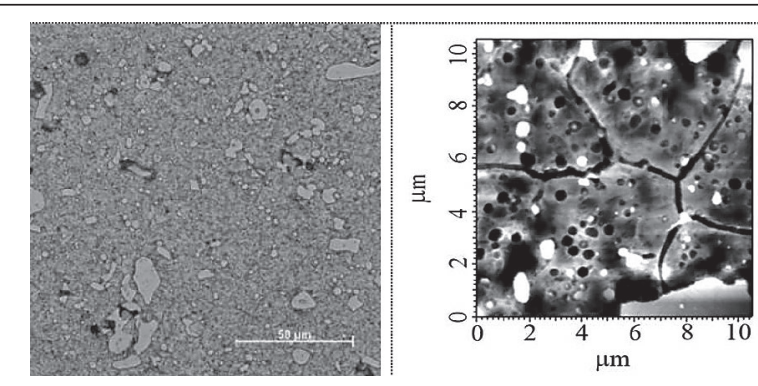

a)

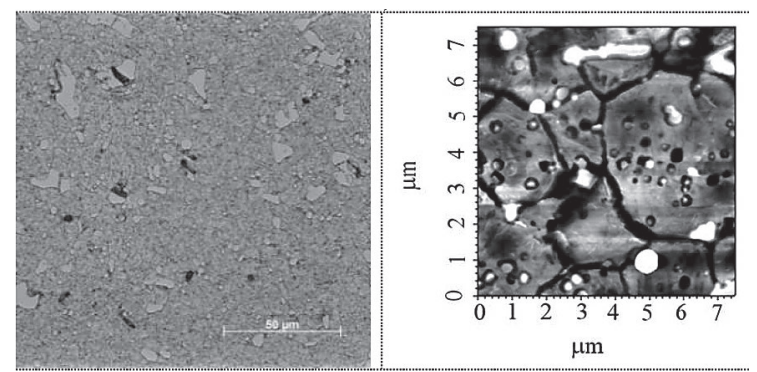

b)
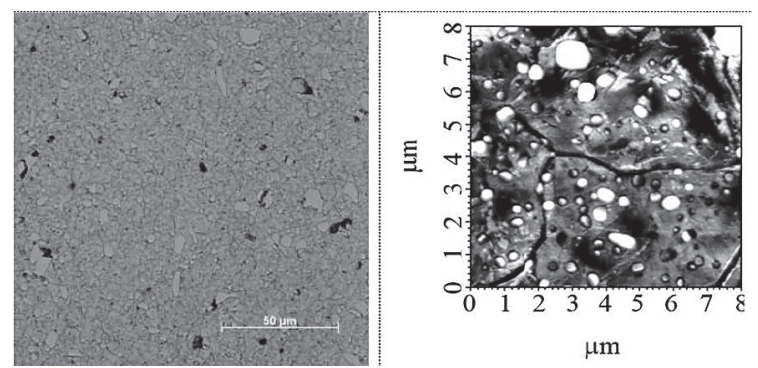

c)
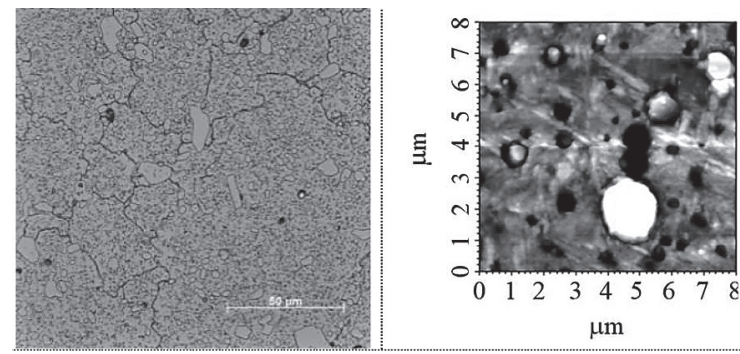

d)
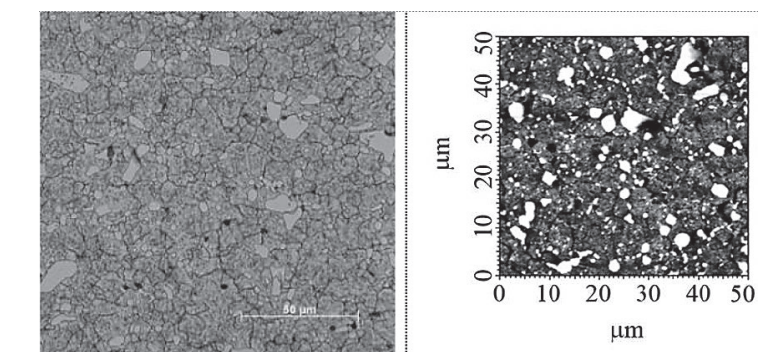

e)
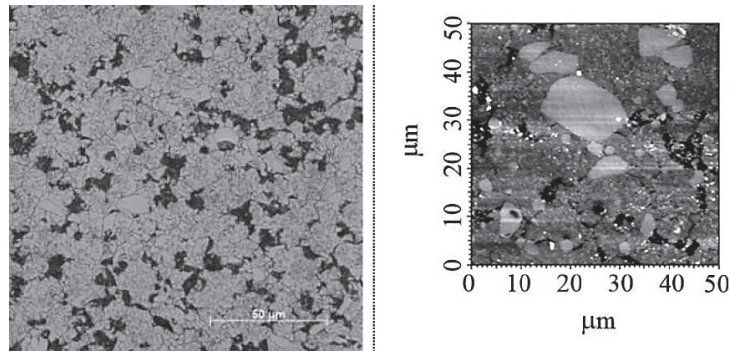

f)
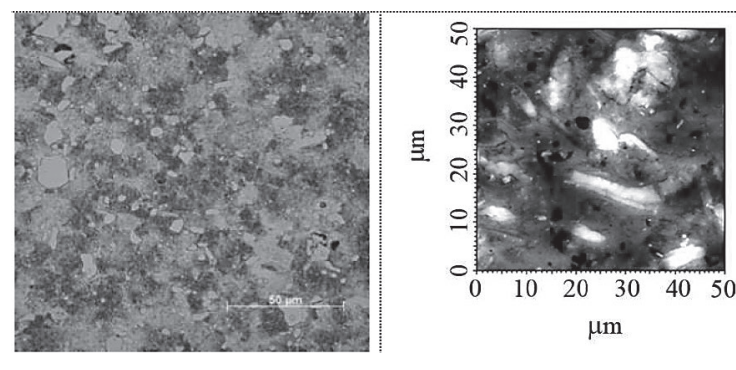

g)

Figure 1 Microstructure of the cooling curves and surface topography by AFM, a) $10^{\circ} \mathrm{C} / \mathrm{s}$, b) $\left.5{ }^{\circ} \mathrm{C} / \mathrm{s}, \mathrm{c}\right) 3^{\circ} \mathrm{C} / \mathrm{s}$, d) $1{ }^{\circ} \mathrm{C} / \mathrm{s}$, e) $0,5^{\circ} \mathrm{C} / \mathrm{s}$, f) $\left.0,2{ }^{\circ} \mathrm{C} / \mathrm{s}, \mathrm{g}\right) 0,1{ }^{\circ} \mathrm{C} / \mathrm{s}$

The microstructure of the first $10^{\circ} \mathrm{C} / \mathrm{s}$ cooling curve was evaluated as martensitic. $\mathrm{M}_{\mathrm{s}}$ temperature was determined as $260{ }^{\circ} \mathrm{C}$. This temperature represents a rate when only the martensitic matrix and the excluded carbides appear in the structure (Figure 1a).

In the Figure 1 the AFM microscope and the grain boundaries are clearly visible. In the figure, there are visible small white areas, representing the carbides, and the dark circular areas, representing the holes that have arisen as the carbides ripped from the matrix during grinding process. Metallographic analysis of the second cooling curve $5{ }^{\circ} \mathrm{C} / \mathrm{s}$ revealed the occurrence of $\mathrm{Cr}_{7} \mathrm{C}_{3}$ carbides, the martensitic matrix (Figure 1b). As can be seen in the previous figure, the grain boundaries and the primary carbides are clearly visible through the AFM microscope. Only few amounts of bainite have already occurred.

At a third cooling curve of $3{ }^{\circ} \mathrm{C} / \mathrm{s}$, the incidence ratio of $\mathrm{Cr}_{7} \mathrm{C}_{3}$ carbides decreased compared to previous cooling rates (Figure 1c). The matrix was composed of martensite and bainite.

At the cooling rate of $1{ }^{\circ} \mathrm{C} / \mathrm{s}$, a greater amount of bainite than martensite was present in the microstructure. There was still a small amount of $\mathrm{Cr}_{7} \mathrm{C}_{3}$ chromium carbides in the matrix (Figure 1d). and the metallographic analysis showed the same occurrence of structures as the expansion of curves. 
Metallographic analysis shows that at the cooling rate of $0,5^{\circ} \mathrm{C} / \mathrm{s}$, the morphology of the carbides in the sample was changed to coarse-grained (Figure 1e). The matrix was predominantly bainite with a low incidence of martensite.

In the metallographic analysis (Figure 1f), in addition to the carbides, about $15 \%$ of pearlite structure was found but was not observed in the dilatation curve. Fe3C carbides precipitated inside of the matrix grains. The AFM microscope shows a surface topography that confirms the occurrence of a coarse-grained structure.

In the last cooling curve, which had the slowest cooling rate of $0,1^{\circ} \mathrm{C} / \mathrm{s}$, the bainitic and martensitic transformation were connected at the end of the curve, for the martensitic transformation was its limit value. It can be assumed that the device did not notice this change due to a very small change in material volume. In this case, the resulting structure was pearlite with coarsely precipitated $\mathrm{Fe}_{3} \mathrm{C}$ carbide according to metallographic analysis (Figure $1 \mathrm{~g})$. Further measurements were not performed because all resulting types of microstructures were achieved.

\section{CCT diagram of X155CrMoV12 steel}

The diagram was constructed from all measured data, i.e. all seven cooling curves. The diagram clearly shows areas of austenite transformation to bainite and martensite. Consequently, at the top we can see the area of pearlitic transformation [5 - 8].

Striped red lines mark the temperatures $\mathrm{Ac}_{1}$ and $\mathrm{Ac}_{3}$, which point to the transformation of the initial state microstructure to austenite while heating of the sample. A long dark line that extends across all curves points to the formation of carbides in the material. As the cooling rate ended at approximately $100{ }^{\circ} \mathrm{C}$, the martensite finish $\mathrm{M}_{\mathrm{f}}$ region was not recorded. At the bottom of each curve, the measured Vickers hardness HV 5 values are shown. We can notice that the hardness dropped smoothly with the reduction in the cooling rate of the material. The initial temperature was set at $1030{ }^{\circ} \mathrm{C}$ on which the time duration was always $10 \mathrm{~min}$. in order to continuously overheat the entire sample throughout the bulk of the material.

We can notice that second cooling curve (cooling rate of $5{ }^{\circ} \mathrm{C} / \mathrm{s}$ ) passes precisely across the boundary that marks the formation of a bainitic change. The critical cooling rate when the pearlite conversion is to be initiated according to the CCT diagram is determined for a cooling rate of approximately $0,15{ }^{\circ} \mathrm{C} / \mathrm{s}$. Compared to the metallographic structure in the cooling curve of 0,2 ${ }^{\circ} \mathrm{C} / \mathrm{s}$, there was not observed any length change due to pearlite formation in the dilatometric curve. This can be due to overlap of the carbide formation and pearlite formation, as each of these processes influence the length change in the opposite direction. The resulting CCT diagram serves as a starting point for the heat treatment of X155CrMoV12 high-strength tool steel (Figure 2).

\section{CONCLUSION}

The phase transformation kinetics was examined in detail using dilatometry, metallographic analysis and nanoindentation hardness test. The results are presented in the form of CCT diagram, which can be useful in designing of the temperature cycles for the production and processing of high performance tool steel X155CrVMo12. The higher percentage of chromium in the mate-

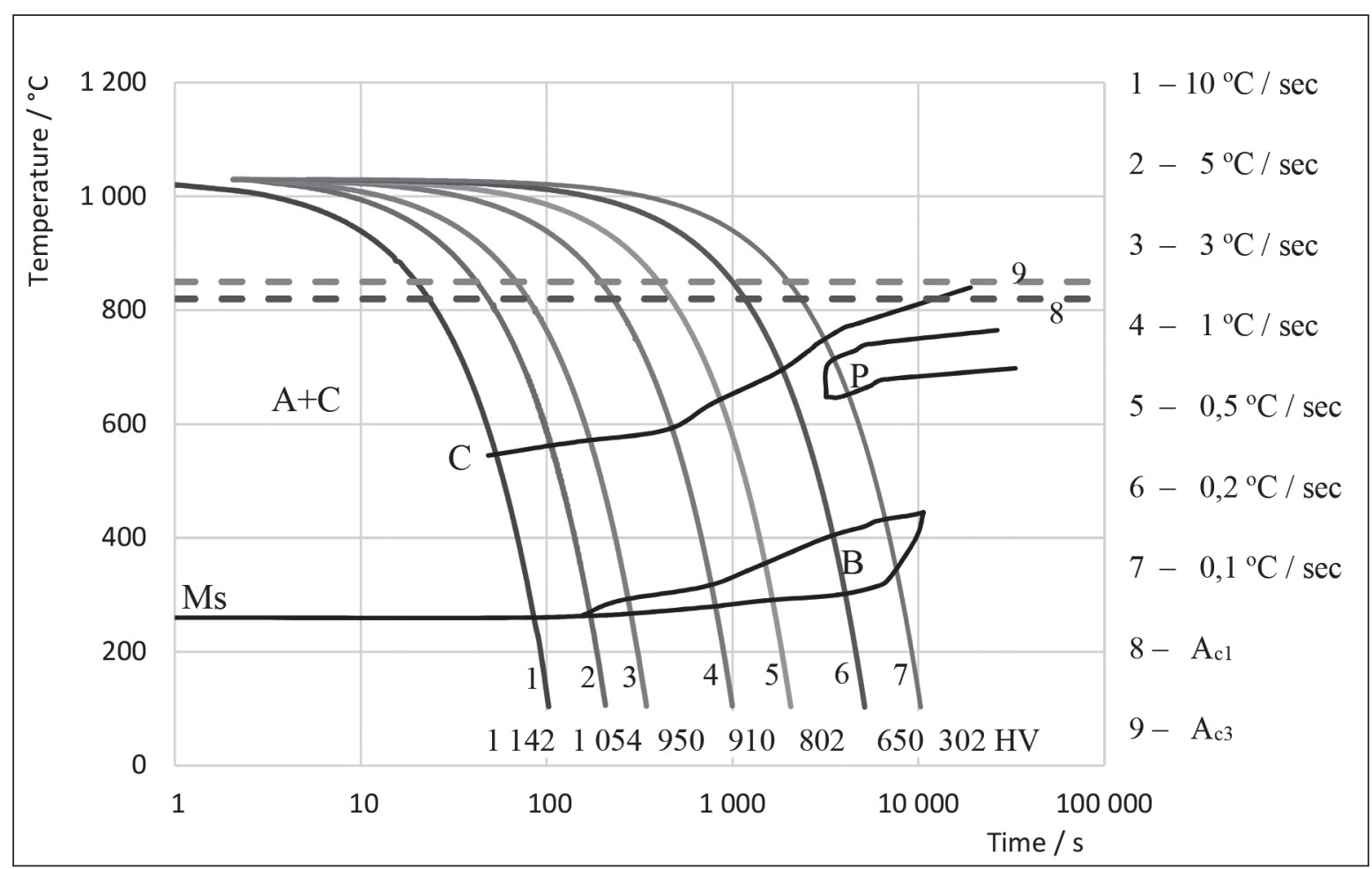

Figure 2 Experimental CCT diagram determined from the analysis of the dilatometry curves in continuous cooling from the intercritical region of $1030^{\circ} \mathrm{C}$. 
rial results in the formation of $\mathrm{Cr}_{7} \mathrm{C}_{3}$ carbide, which results in an increased value of the hardness of the material $[9,10]$. Provided the martensitic transformation is achieved, the resulting critical cooling rate is set at 5 ${ }^{\circ} \mathrm{C} / \mathrm{s}$. This rate is precisely bordered where literature sources suggests that triple tempering should be followed to achieve the resulting uniform structure of the material. The results of chromium carbides show that at high cooling rates the incidence of hard carbides occur. With decreasing of cooling rates, $\mathrm{Fe}_{3} \mathrm{C}$ carbides are beginning to occur. Using the AFM microscope, surface topographies of each sample were evaluated to clearly show the sizes of the individual types of carbides as well as their distributions. The highest hardness achieved value of $1143 \mathrm{HV}$ at the highest cooling rate of $10^{\circ} \mathrm{C} / \mathrm{s}$. The value of this hardness is mainly affected by the large occurrence of $\mathrm{Cr}_{7} \mathrm{C}_{3}$ and martensitic matrix.

\section{Acknowledgement}

This work was supported by the Slovak Research and Development Agency under the contract No. APVV-15-0710.

\section{REFERENCES}

[1] P. Jurči, J. Cejp, J. Brajer, Metallurgical aspects of laser surface processing of PM Cr-V ledeburitic steel, Advances in Mater. Science and Engineering 2 (2011).
[2] M. Pašák, R. Čička, P. Bílek, P. Jurči, L. Čaplovič, Study of phase transforma-tions in $\mathrm{Cr}-\mathrm{V}$ tool steel, Materiali in Tehnologije 14 (2014), 693-696.

[3] J. Man, K. Obrtlík. C. Blochwitz, J. Polák, Atomic force microscopy of surface relief in individual grains of fatigued 316L austenitic stainless steel, Acta Materialia (2002), 3767-3780.

[4] J. Mana, B. Valtr, M. Weidnerc. M. Petrenec, K. Obrtlík, J. Polák, AFM study of surface relief evolution in 316L steel fatigued at low and high temperatures, Procedia Engineering 2 (2010), 1625- 1633.

[5] Y. Wei, X. Wei-hong, L. Ya-xiu, B. Bing-zhe, F. Hongsheng, Effect of Chromium on CCT Diagrams of Novel Air-Cooled Bainite Steels Analyzed by Neural Network, Journal of Iron and Steel Research14 (2007), 69-74.

[6] H. Jirková, L. Kučerová, B. Mašek, The Effect of Chromium on Microstructure Development During Q-P Process, Materials today (2015), 627-630.

[7] A. D. Schino, Analysis of phase transformation in high strength low alloyed steels, Metalurgija 56 (2017)3-4, 349-352.

[8] J. Zrník, I. Mamuzić, S. V. Dobatkin, Recent progress in high strength low carbon steels, Metalurgija 45(2006)4, 323-331.

[9] M. Krbat'a, M. Eckert, D. Križan, I. Barényi, I. Mikušova, Hot Deformation process analysis and modelling of X153CrMoV12 steel, Metals 9 (2019), 1125-1142.

[10] I. Barényi, J. Majerík, Z. Pokorný, J. Sedlák et al., Material and technological investigation of machined surfaces of the OCHN3MFA steel, Kovové Materiály 57 (2019), 131-142.

Note: The responsible person for translation is prof. Martina Šuto, University of Osijek. 